\title{
The Production of Patents and Evolution of the Production of Knowledge around Snow Avalanches
}

\author{
Luis G Lopez-Cobo
}

Andorra

Received: November 20, 2014 / Accepted: December 20, 2014 / Published: January 25, 2015.

\begin{abstract}
Scientific research on snow avalanches is relatively modern, yet in constant and rapid evolution, as the multiple disciplines involved in its development will, in turn, become more specialized and more technical. Patents are part of research and knowledge production. The scientific community and policy makers are increasingly interested in production of knowledge collaboratively. Almost all of the research being conducted on snow avalanches uses technology, technique or instrumentation. One main objective of this study is to draw from the literature the many technologies, techniques and instrumentations that are being used in research related to avalanches. Thus, a textual analysis of the most significant literature in the field of snow avalanches was done. In this analysis, techniques, technologies and instrumentations have emerged. A patent search has been done in databases. Subsequently, patents were conceptualized. The proportion of applicants for patents is higher in industry than in universities. The measure of exploration of the ongoing sociocognitive transformations of science and technology systems presents a useful tool to conduct a study to explore these transformations. It would be interesting for the scientific community, but also for the industry, to elaborate concept mapping when applied to avalanche research, which would help in determining referents.
\end{abstract}

Key words: Avalanches, patents, knowledge, conceptual map, technology, collaboration.

\section{Introduction}

\subsection{Patents}

Based on a literature review of the concepts of dissemination of scientific knowledge, or the transfer of knowledge, between the scientific and patent or collaborative work between knowledge producers, we first have outlined a previous introduction to the current state of the patents in the field of knowledge.

There has been a search for patents related to snow avalanches and a descriptive analysis of the same. This search has defined patent categories and their time trends for the past 20 years.

Patents are part of research and knowledge production. Patents have advantages and disadvantages and some impact on the economy and society [1].

Corresponding author: Luis G Lopez Cobo, freelance researcher, research fields: snow avalanches knowledge transfer, educational game design and game based learning. E-mail: egoprepi@gmail.com.
Complex interactions of science and technology between universities, public research institutions and industries do not follow a definite pattern, but depends on the organizations. As for the publication of scientific results, lectures and technical bulletins play a substantial role in the dissemination of scientific results and technological patents by companies. In terms of methodology, patent citations present gaps of traceability in interactions between science and technology. Tacit knowledge and other references appear in patents that are not documents set by the SCI (Science Citation Index) [2].

Furthermore, a study by Powell [3] concludes that the scientific literature on the knowledge economy focuses much on production but poorly on the spread and impact of knowledge. Similarly, patents have become an appropriate stock of knowledge.

The interdependency of organizations, limited dissemination and the impact of knowledge are reflected in a study of Carayol [4, 5], who found that 
appropriate combinations of research staff can strongly influence productivity in publications and patents.

However, patenting capacity depends on the different scientific fields [6]. In terms of quality, there is a positive correlation between patent production and quality of the scientific product published in international journals mainly representing scientific research activity [7] quoted by Tuzi [6].

Analyzing interregional scientific collaboration as measured by scientific publications and patents, show the effects of geographical distance and institutional research collaboration. Elite structures were detected between regions of excellence and capitals regions, which may take into account the cohesion policies of the region and its policies on science [8]. Physical distance and languages involved are a negative factor of scientific collaboration, despite the fact that a common language promotes intraregional collaborations. Europe is still far from being a fair field of collaborative research opportunities [9]. As an example, the authors mention the life sciences and physical sciences as the most Europeanized, while engineering sciences and physical sciences both have a high level of regional embeddedness, and need a promotion of cross-border collaboration.

Entering the issue of international collaboration for knowledge production, intra-regional, interregional or international interchange are increasingly expanding through the use of participation in innovation networks by reducing the degree of uncertainty and providing different types of knowledge, including the tacit [10], cited by Gao [11].

There are different mechanisms for knowledge exchange: the patented invention and collaborative patent, technical collaboration between companies, universities and public research institutions, and the diffusion of knowledge and technology in enterprises adopting new technology and staff mobility between the public and private sectors. The scientific community and policy makers are increasingly interested in the production of knowledge collaboratively [11].

Some decision makers argue that universities are under-exploited in their potential for accelerating industrial innovation. The traditional incentive of scientific research, characterized by the sharing of knowledge, seems to give way to others, where the selection of projects drives onto the detriment of basic research. The increasing funding from companies can reduce the production in quantity and quality of researchers, but can also produce a positive impact on the quality of applied research, as measured by patent citations. This carries implications for policy makers and funding authorities for investigation, which stimulates technology transfer between science and industry [12]. In another study [13] distinguish two motivations adopted by researchers from universities in relation to patent: a proactive, enthusiastic motivation and a reactive one.

Parent [14] analyzed the production of knowledge and patents from the spatial perspective, with conclusions on technology transfer, considering variables such as regional knowledge stocks: humans drive to innovate, scientific and technical capabilities, public and private investments, government policy and the regional structure and indicators of regional technological gaps. Regional growth in innovation depends on human resources devoted to the development of research studies and technology, as well as the spatial interdependence between regions aimed at innovation. European technological change is largely determined by the diffusion of interregional technology. Human capital levels stimulate innovative activity in a region, and increase the ability to leverage technologies from neighboring regions.

\subsection{Technologies}

Scientific research on snow avalanches is relatively modern, yet in constant and rapid evolution, as the multiple disciplines involved in its development will, in turn, become more specialized and more technical. 

Knowledge around Snow Avalanches in A Collaborative

The proposals of Leydesdorff and Rafols $[15,16]$ in measuring exploration of the ongoing sociocognitive transformations of science and technology systems using 2D representations of scientometric indicators, present a useful tool we propose to the scientific community to conduct a study to explore these transformations in sciences that study snow avalanches. It is a complementary tool in the conceptuality of different lines of research and can aid in the management and research policy.

The number and diversity of sciences and technologies applied to the investigation of snow avalanches is profuse and confusing for the neophyte. A literature review based on the scientific literature shows that the use of multiple technologies began with some significance from the 80 s but its development has been explosive during the first decade of this century.

On the other hand, some lines of research have been identified among the most relevant literature related to snow avalanches. This non-exhaustive list compromises areas of research that are making progress in the scientific community, which are interrelated, forming a conceptual map of this highly multidisciplinary research [17].

It could be shown with further study how the interplay of disciplines grows as the use of new technologies is incorporated into the research.

The main objective of this study is to draw from the literature the many technologies, techniques and instrumentations that are being used in research related to snow avalanches.

Later, with the diversity of technologies found, we propose the creation of a map similar to Leydersdorff and Rafols to explore the transformations in the sciences that study snow avalanches.

Leydersdorff and Rafols maps help in: determining referents, determining scientific collaboration and complementation or research collaboration and by tracing the evolution of research both in universities, research funding agencies, industry, between the issues or lines of research and in the development of emerging research topics.

It is impossible to show here all the technologies, techniques and instrumentations that are involved in the various stages of research that the international scientific community investigates in snow avalanches, given the methodological limitations of this study. Moreover, some of those, because of their recent introduction or development, are in continuous development and evolution.

We present results from a textual analysis of the most significant literature found in the bibliographic database WoS (Web of Science) of research related to snow avalanches.

In this analysis, techniques, technologies and instrumentations have emerged related to research of snow avalanches.

\section{Method}

\subsection{Patents}

For our patent search we have used the database WIPO (World Intellectual Property Organization). The search period comprises between 1992 and 2012.

The search results have been filtered by the disambiguation of keywords used to search in English: "snow" and "avalanches". Content analysis is used to identify the topics that appear in the texts. We proceed to identify texts in an objective and systematic way, arranged in patterns to classify patents into categories. This analysis examines only the manifest content as they are strictly technical texts.

Subsequently, patents are conceptualized, grouping them into categories based on the common attributes they share.

The result of the database search gave 344 gross patents. The refinement process is a result of the analytical result. This led to a final amount of 165 patents, most directly related to snow avalanches, but some of them indirectly related because of their possible usefullness in the context of snow avalanches. 
(1) Refinement procedure on the first raw results, which implements the following criteria:

a Date: publications after the first day of 1992. Patents eliminated $=24$;

b Relevance: Many patents appeared irrelevant by the polysemy of the search words. Patent removed $=$ 155.

During the analysis we concentrated on the fields of patents database by following the following priority:

1st: title; 2nd: abstract; 3rd: full text content.

(2) Analysis of the resulting patents by different criteria:

Classification of the 165 patents resulting from the refining of search categories: first conceptualization, then ranking not exclusive.

The analysis of trends over time category of patents.

The analysis according to International Classification code more abundant patent.

Analysis of the inventors based on their frequency of publication.

\subsection{Technologies}

The methodology establishes firstly a selection of information sources. It performs a search of scientific publications in the WoS database from the English keywords "snow" and "avalanches" between 1950 and 2011. Then we analyzed the 1254 results, sortable by the number of citations received.

Secondly, we establish the criteria of content analysis, establishing the sequence of priorities

1st: title and abstract; 2nd: full paper, when it is arranged; 3rd: title, in the absence of abstract and full paper. Thirdly, in a first analysis of debugging the search results of scientific publications we discarded irrelevant publications grouped in this study, either by the subject or for reasons of disambiguation. This group is composed of 201 publications discard.

Finally, we separated techniques, technologies and instrumentations into categories, with their references associated.

\section{Results and Discussion}

\subsection{Patents}

(1) Table purged of patents related to snow avalanches.

(2) The categories of patents related to snow avalanches that have been generated, Fig. 1:

- Retention and protection;

- Detection of victims;

- Monitoring of snow avalanches;

- Triggering of snow avalanches;

- Decreased risk of snow avalanches;

- Study of Snow.

(3) Other results:

The analysis of trends over time of categories of patents.

The analysis according to the International Classification code more abundant patent.

Analysis of the inventors based on their frequency of publication.

\subsection{Technologies}

Almost all of the research being conducted on snow avalanches uses some sort of technology, technique or instrumentation. Despite of this, we have selected 98 outstanding publications in these areas.

The results are limited by the methodology used.

The various technologies, techniques and instrumentation categorized, could be grouped in a significantly lower number of families, and in turn establish the relationships between them in the practice of investigating snow avalanches. However, we preferred to keep the list to not remove ungrouped details. They are:

Automatic acoustic detection [18]; Automatic digital photography [19, 20]; Automatic Weather Stations [21]; Avalanche dynamics models [22]; Decision trees and knowledge-based models [23]; Digital image [20, 24, 25]; Digital scanner [26, 27]; Electronic sensors [28-33]; ELF Extreme Low Frequency detection [34]; Extended Kalman Filter, 


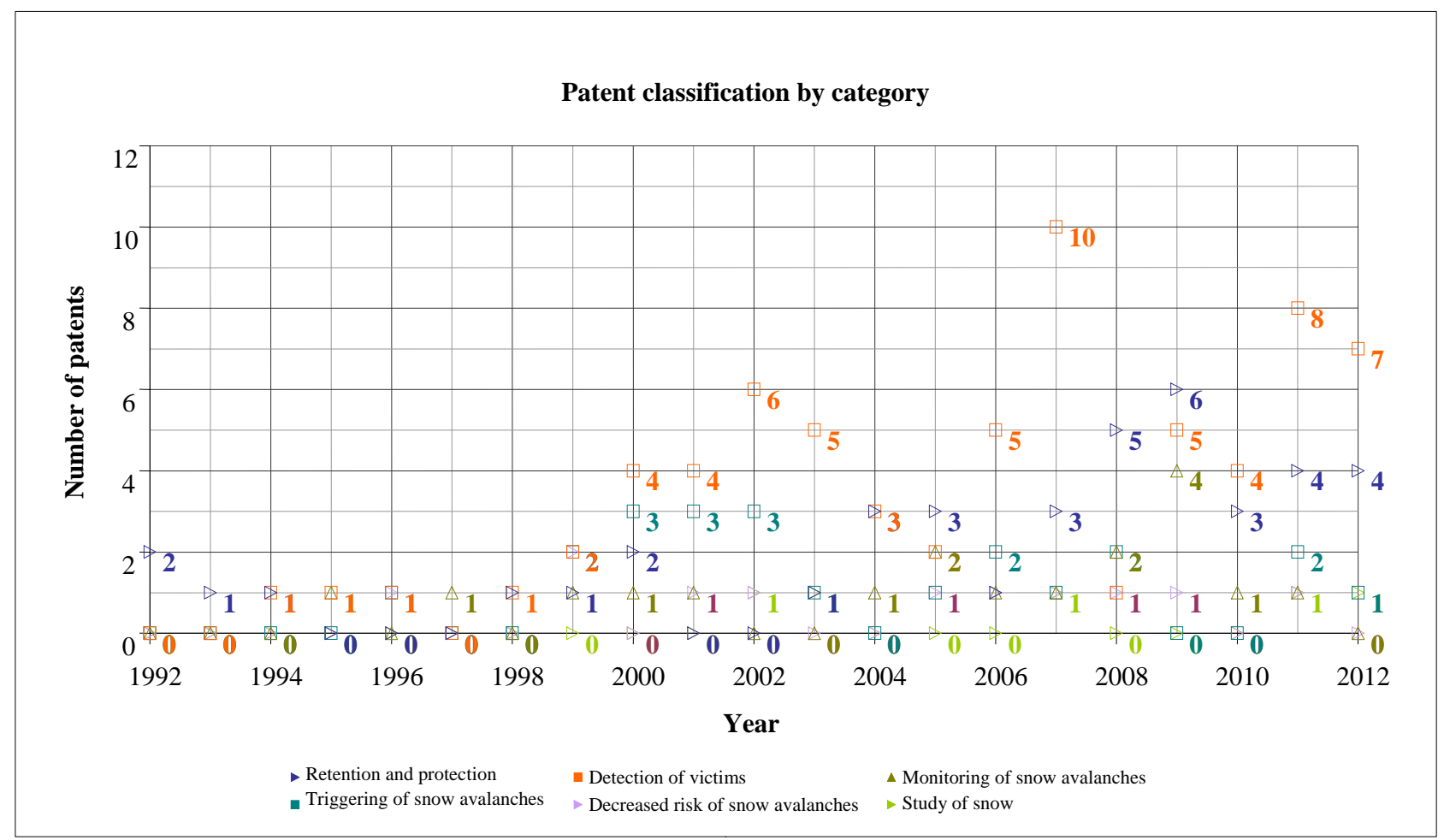

Fig. 1 Patent classification by category. ${ }^{1}$

[33, 35, 36,]; FMCW Radars High Frequency Microwave [37-39]; Gaussian sums Filter SOGS [35, 36]; Geographic Information Systems [40-46]; GPS Global Position System [47-52]; High speed video [53]; Images MODIS Moderate Resolution Spectroradiometer [21]; Images $\mathrm{X}$ and $\mathrm{Ku}$ band satellite [54]; Impact pressure sensors [55, 28]; Indices; Infrasound [56-58]; Inverse analysis techniques, [59]; Laser rangefinder [60]; Low Frequency Radar penetrating earth (GPR) [61-64]; Microtomography, 3D computed microtomography X-ray [65]; Microwave images [66-70]; Microwave radiometry [71]; Numerical models of stratigraphy; Numerical prediction models [72]; Optical reflectance measurement wavelengths near infrared [73, 20]; Optoacoustic Spectrometry [74]; Penetrometers and micropenetrometers [38, 75, 30]; Phones with tracking systems [51]; Probabilistic models of avalanches; Pulsed Doppler Radar, [76]; Radar Images, LISA, GB-SAR [26, 27, 77-82]; LIDAR [83, 84, 85, 70, 22];

\footnotetext{
${ }^{1 .}$ Fig. 1: Classification by category and year of publication of patents related to snow avalanches, between 1992 and 2012.
}

Rain gauge high precision, [86]; Remote Aviation small format (UASs) [87]; Remote Sensing [22, 26, 27, 40, 41, 43-46, 54, 66, 88-93, 80]; Rescue transceivers [50, 94, 95,]; Scanning electron microscopy, [96]; Seismic sensors [48, 55, 58, 97-101]; Seismometers [99]; SLAM Simultaneous Localization and Mapping, [36]; Snow microwave resonant "snow fork" [32]; Software [25, 30, 102,]; Space systems risk management [48]; Spatial patterns,[103]; Statistical methods; Tachymetry [37, 104]; Terrestrial Laser scanners [37, 104-107]; Time Domain Reflectometry [108, 109]; Time-frequency representations [110]; Total Stations; Ultra Wideband Radar [111-113]; Up Impulse Radar Systems upGPR; Virtual network models [72]; WiFi [31, 33].

\section{Conclusions}

\subsection{Patents}

There is a significant increase since the year 2000 in the number of patents issued annually related to avalanches. 

Knowledge around Snow Avalanches in A Collaborative

The victims detection category is the one that has increased most in the study period.

The triggering of avalanches category has a continuous presence since 2000 .

The international classification code most often appeared is E01F 7/04 involving devices which provide protection against falling rocks and avalanches, e.g., avalanche structures, galleries. The retention and protection category, that contains this classification code, is the category most evenly distributed among all categories of patents. And it is holds the oldest patents in the study period.

Applicants for patents are both from research centers, universities, industries and individuals. But the proportion is higher in industry and lower in universities.

\subsection{Technologies}

The study of snow avalanches as a field of science is both multidisciplinary and multi-technological.

It would be interesting for the scientific community, but also for the industry, to elaborate on Leydersdorff and Rafols methodology of concept mapping when applied to snow avalanche research, which would help in determining referents, in the determination of scientific collaboration and complementation in tracing the evolution of research both in universities, research funding agencies, and between the same themes or lines of research, as well as in the development of emerging research.

\section{Acknowledgements}

Luis G. López Cobo acknowledges a mobility grant from Government of Andorra, AM2013-002-AND.

\section{References}

[1] Gambardella, A., Giuri, P., Mariani, M., Giovannoni, S. 2005. "Study on Evaluating the Knowledge Economy What Are Patents Actually Worth? The Value of Patents for Today's Economy and Society”. Technical report for the European Commission research project (ETD/2004/IM/E3/77). .

[2] Bhattacharya, S., and Meyer, M. 2003. "Large Firms and the Science-Technology Interface-Patents, Patent Citations, and Scientific Output of Multinational Corporations in Thin Films.” Scientometrics 58 (2): 265-79.

[3] Powell, W. W., and Snellman, K. 2004. "The Knowledge Economy.” Annual Review of Sociology 30: 199-220.

[4] Carayol, N., and Matt, M. 2004. "Does Research Organization Influence Academic Production? Laboratory Level Evidence from a Large European University.” Research Policy 33 (8): 1081-102.

[5] Carayol, N., and Matt, M. 2004. "The Exploitation of Complementarities in Scientific Production Process at the Laboratory Level.” Technovation 24 (6): 455-65.

[6] Tuzi, F. 2005. "Useful Science is Good Science: Empirical Evidence from the Italian National Research Council.”Technovation 25 (5): 505-12.

[7] Pavitt, K. 1998. "The Social Shaping of the National Science Base.” Research Policy 27: 793-805.

[8] Hoekman, J., Frenken, K., and van Oort, F. 2009. "The Geography of Collaborative Knowledge Production in Europe.” Annals of Regional Science 43 (3): 721-38.

[9] Hoekman, J., Frenken, K., and Tijssen, R. J. W. 2010. "Research Collaboration at a Distance: Changing Spatial Patterns of Scientific Collaboration within Europe." Research Policy 39 (5): 662-73.

[10] Scherngell, T., and Barber, M. J. 2009. "Spatial Interaction Modelling of Cross-Region R\&D Collaborations: Empirical Evidence from the EU Framework Programmes.” Papers in Regional Science 88 (3): 531-46.

[11] Gao, X., Guan, J., and Rousseau, R. 2011. "Mapping Collaborative Knowledge Production in China Using Patent Co-Inventorships.” Scientometrics 88 (2): 343-62.

[12] Hottenrott, H., and Thorwarth, S. 2011. "Industry Funding of University Research and Scientific Productivity."Kyklos 64 (4): 534-55.

[13] Hussler, C., and Penin, J. 2012. "Proactive Versus Reactive Motivations for Patenting and Their Impact on Patent Production at Universities.” International Journal of Technology Management 58 (3-4): 213-35.

[14] Parent, O., and LeSage, J. P. 2012. "Determinants of Knowledge Production and Their Effects on Regional Economic Growth.” Journal of Regional Science 52 (2): 256-84.

[15] Leydesdorff, L., and Rafols, I. 2009. “A Global Map of Science Based on the ISI Subject Categories.” Journal of the American Society for Information Science and Technology 60 (2): 348-62.

[16] Rafols, I., Porter, A., and Leydesdorff, L. 2010. "Science Overlay Maps: A NewTool for Research Policy and Library Management”. Journal of the American Society for Information Science and Technology 61 (9): 1871-87. 


\section{The Production of Patents Related to Snow Avalanches and Notes for the Evolution of the Production of Knowledge around Snow Avalanches in A Collaborative}

[17] López-Cobo, L. G. 2013. “Qualitative Analysis of the Transfer of Knowledge about Snow Avalanches in the Land Use Planning of Four Territories of Europe-Qualitative Analysis and Conceptual Map.” In International Snow Science Workshop, 649-56.

[18] Chritin, V., Rossi, M., and Bolognesi, R. 1996. "Snow Avalanches: Automatic Acoustic Detection for Operational Forecasting.”Acustica 82: 173.

[19] Christiansen, H. 2001. "Snow-Cover Depth, Distribution and Duration Data from Northeast Greenland Obtained by Continuous Automatic Digital Photography.” Annals of Glaciology 32: 102-8.

[20] Tape, K. D., Rutter, N., Marshall, H., Essery, R., and Sturm, M. 2010. "Recording Microscale Variations in Snowpack Layering Using Near-Infrared Photography.” Journal of Glaciology 56 (195): 75-80.

[21] Negi, H. S., Thakur, N. K., and Nushra, V. D. 2007. "Estimation and Validation of Snow Surface Temperature Using Modis Data for Snow-Avalanche Studies in NW-Himalaya." Photonirvachak-Journal of the Indian Society of Remote Sensing 35 (4): 287-99.

[22] Buehler, Y., Christen, M., Kowalski, J., and Bartelt, P. 2011. "Sensitivity of Snow Avalanche Simulations to Digital Elevation Model Quality and Resolution.” Annals of Glaciology 52 (58): 72-80.

[23] Naresh, P., and Pant, L. 1999. "Knowledge-Based System for Forecasting Snow Avalanches of Chowkibal-Tangdhar Axis (J\&K).” Defence Science Journal 49 (5): 381-91.

[24] Latombe, B., Ladret, P., Granada, F., and Villemain, P. 1997. "An Original Active Contour Algorithm Applied to Snow Avalanches.” In Sixth International Conference on Image Processing and its Applications, 404-8.

[25] Tsuda, Y., Yue, Y., Dobashi, Y., and Nishita, T. 2010. "Visual Simulation of Mixed-Motion Avalanches with Interactions between Snow Layers.” Visual Computer 26 (6-8): 883-91.

[26] Buehler, Y., Hueni, A., Christen, M., Meister, R., and Kellenberger, T. 2009. “Automated Detection and Mapping of Avalanche Deposits Using Airborne Optical Remote Sensing Data.” Cold Regions Science and Technology 57(2-3): 99-106.

[27] Buehler, Y., Hueni, A., Christen, M., Meister, R., and Kellenberger, T. 2009. Automated Detection and Mapping of Rough Snow Surfaces including Avalanche Deposits Using Airborne Optical Remote Sensing. Birmensdorf: Snow \& Landscape Res, Library Wsl.

[28] Henderson, T., Grant, E., Luthy, K., and Cintron, J. 2004. "Snow Monitoring With Sensor Networks". In Proceedings of the 29th Annual IEEE International Conference on Local Computer Networks, 558-9.

[29] Alippi, C., Anastasi, G., Galperti, C., Mancini, F., and
Roveri, M. 2007. Adaptive Sampling for Energy Conservation in Wireless Sensor Networks for Snow Monitoring Applications. New York: IEEE.

[30] Andrae, S., Gruber, G., Hecke, A., and Wieser, A. 2009. Sensor Web Enablement-Standards and Open Source Implementations for Observation Data. Birmensdorf: Snow \& Landscape Res, Library Wsl.

[31] Vilajosana, I., Llosa, J., Schaefer, M., Surinach, E., Marques, J. M., and Vilajosana, X. 2009. Wireless Sensors as a Tool to Explore Avalanche Internal Dynamics: Experiments at the Weissfluhjoch Snow Chute. Birmensdorf: Snow \& Landscape Res, Library Wsl.

[32] Techel, F., and Pielmeier, C. 2011. "Point Observations of Liquid Water Content in Wet Snow-Investigating Methodical, Spatial and Temporal Aspects.” Cryosphere 5 (2): 405-18.

[33] Vilajosana, I., Llosa, J., Schaefer, M., Surinach, E., and Vilajosana, X. 2011. "Wireless Sensors as a Tool to Explore Avalanche Internal Dynamics: Experiments at the Weissfluhjoch Snow Chute.” Cold Regions Science and Technology 65 (2): 242-50.

[34] Cechak, J. 2005. Measuring of the Human Electromagnetic Emission in the ELF Band. Athens: World Scientific and Engineering Acadand Soc.

[35] Pinies, P., and Tardos, J. D. 2006. "Fast Localization of Avalanche Victims Using Sum of Gaussians.” In International Conference on Robotics and Automation, 3989-94.

[36] Pinies, P., Tardos, J. D., and Neira, J. 2006. Localization of Avalanche Victims Using Robocentric SLAM. New York: IEEE.

[37] Gubler, H., and Hiller, M. 1984. "The Use of Microwave Fmcw Radar in Snow and Avalanche Research.” Cold Regions Science and Technology 9 (2): 109-19.

[38] Marshall, H., Schneebeli, M., and Koh, G. 2007. "Snow Stratigraphy Measurements with High-Frequency FMCW Radar: Comparison with Snow Micro-Penetrometer." Cold Regions Science and Technology 47 (1-2): 108-17.

[39] Ash, M., Chetty, K., Brennan, P., McElwaine, J., and Keylock, C. 2010. "FMCW Radar Imaging of Avalanche-Like Snow Movements.” In Radar Conference 2010 IEEE, 102-7.

[40] Walsh, S., Brown, D., and Bian, L. 1990. “Comparison of Landsat Thematic Mapper Digital Enhancements of Snow-Avalanche Paths-Validation Through GIS/Remote Sensing Integration”. Remote Sensing Science for the Nineties 1-3: 1161-64.

[41] Walsh, S., Butler, D., Brown, D., and Bian, L. 1990. "Cartographic Modeling of Snow Avalanche Path Location within Glacier-National-Park, Montana.” Photogrammetric Engineering and Remote Sensing 56 (5): $615-21$. 
[42] Barka, I., and Rybar, R. 2003. "Identification of Snow Avalanche Trigger Areas Using GIS." Ekologia-Bratislava 22: 182-94.

[43] Weibel, D., Wunderle, S., and Kleindienst, H. 2003. A Distributed Model to Simulate the Snow Cover in Switzerland Combining GIS and RS. Rotterdam: Millpress Science Publishers.

[44] Flueraru, C., Stancalie, G., Catana, S., Savin, E., and Irimescu, A. 2005. Estimation of Snow Cover Extent in Carpathian Mountains Using Integrated GIS and Remote Sensing Information. New York: IEEE.

[45] Foppa, N., Stoffel, A., and Meister, R. 2007. "Synergy of In Situ and Space Borne Observation for Snow Depth Mapping in the Swiss Alps.” International Journal of Applied Earth Observation and Geoinformation 9 (3): 294-310.

[46] Tao, J. 2007. "Snow Hazard Potential Evaluation Along G217 Highway in Tianshan Mountains by Using GIS And RS”. Proc. SPIE 6790, MIPPR 2007: Remote Sensing and GIS Data Processing and Applications; and Innovative Multispectral Technology and Applications 67901A.

[47] Stepanek, J., and Claypool, D. 1997. "GPS Signal Reception under Snow Cover: A Pilot Study Establishing the Potential Usefulness of GPS in Avalanche Search and Rescue Operations.” Wilderness \& Environmental Medicine 8 (2): 101-4.

[48] Shamshi, M. 2004. "Technologies Convergence in Recent Instrumentation for Natural Disaster Monitoring and Mitigation.” IETE Technical Review 21 (4): 277-90.

[49] Schleppe, J. B., and Lachapelle, G. 2006. GPS Tracking Performance under Avalanche Deposited Snow. Washington: Inst Navigation.

[50] Schleppe, J. B., and Lachapelle, G. 2008. "Tracking Performance of a HSGPS Receiver under Avalanche Deposited Snow”. GPS Solutions 12 (1): 13-21.

[51] Suter, C., and Harvey, S. 2009. Mobile Information Systems for Avalanche Topics. Birmensdorf: Snow \& Landscape Res, Library Wsl.

[52] Klimanek, M., Mikita, T., Lizuch, M., Janata, P., and Cibulka, M. 2011. "Using GPS for Snow Depth and Volume Measurement of Centennial Avalanche Field in High Tatras.” Cold Regions Science and Technology 65 (3): 392-400.

[53] Schaefer, M., and Kern, M., 2009. High-Speed Video Recording in Snow Chute Experiments.Birmensdorf: Snow \& Landscape Res, Library Wsl.

[54] Wiesmann, A., Strozzi, T., Werner, C., Wegmueller, U., and Santoro, M. 2007. Microwave Remote Sensing of Alpine Snow. New York: IEEE.

[55] Salway, A. 1978. "Seismic and Pressure Transducer System for Monitoring Velocities and Impact Pressures of Snow Avalanches.” Arctic and Alpine Research 10 (4): 769-74.

[56] Adam, A., Chritin, V., Rossi, M., and Van Lancker, E. 1998. "Infrasonic Monitoring of Snow-Avalanche Activity: What do We Know and Where do We Go from here?” Annals of Glaciology 26: 324-8.

[57] Scott, E. D., Hayward, C. T., Kubichek, R. F., Hamann, J. C., Pierre, J. W., Comey, B., and Mendenhall, T. 2007. "Single and Multiple Sensor Identification of Avalanche-Generated Infrasound.” Cold Regions Science and Technology 47 (1-2): 159-70.

[58] Kogelnig, A., Surinach, E., Vilajosana, I., Huebl, J., Sovilla, B., Hiller, M., and Dufour, F. 2011. "On the Complementariness of Infrasound and Seismic Sensors for Monitoring Snow Avalanches.” Natural Hazards and Earth System Sciences 11 (8): 2355-70.

[59] Gauer, P., Kronholm, K., Lied, K., Kristensen, K., and Bakkehoi, S. 2010. "Can We Learn More from the Data Underlying the Statistical Alpha-Beta Model with Respect to the Dynamical Behavior of Avalanches?” Cold Regions Science and Technology 62 (1): 42-54.

[60] Hood, J. L., and Hayashi, M. 2010. “Assessing the Application of a Laser Rangefinder for Determining Snow Depth in Inaccessible Alpine Terrain.” Hydrology and Earth System Sciences 14 (6): 901-10.

[61] Jaedicke, C. 2003. "Snow Mass Quantification and Avalanche Victim Search by Ground Penetrating Radar." Surveys in Geophysics 24 (5-6): 431-45.

[62] Modroo, J., and Olhoeft, G. 2004. Avalanche Rescue Using Ground Penetrating Radar. New York: IEEE.

[63] Heilig, A., Schneebeli, M., Fellin, W. 2008. "Feasibility Study of a System for Airborne Detection of Avalanche Victims with Ground Penetrating Radar and a Possible Automatic Location Algorithm.” Cold Regions Science and Technology 51 (2-3): 178-90.

[64] Fruehauf, F., Hellig, A., Schneebeli, M., Fellin, W., and Scherzer, O. 2009. "Experiments and Algorithms to Detect Snow Avalanche Victims Using Airborne Ground-Penetrating Radar.” IEEE Transactions on Geoscience and Remote Sensing 47 (7): 2240-51.

[65] Schneebeli, M. 2002. "The Importance of the Microstructure of Snow in Nature and Engineering." Design and Nature: Comparing Design in Nature with Science and Engineering 3: 87-93.

[66] Sharma, S., Mathur, P., and Snehmani. 2004. "Change Detection Analysis of Avalanche Snow in Himalayan Region Using near Infrared and Active Microwave Images.” Monitoring of Changes Related to Natural and Manmade Hazards using Space Technology 33 (3): 259-67.

[67] Mishra, V. D., Mathur, P., and Singh, R. P. 2005. "Qualitative and Quantitative Analysis of Snow 
Parameters Using Passive Microwave Remote Sensing.” Photonirvachak-Journal of the Indian Society of Remote Sensing 33 (3): 381-93.

[68] Singh, K. K., and Mishra, V. D. 2006. "Snowcover Study of NW-Himalaya Using Passive Microwave Remote Sensing Data.” Proc. SPIE 6410, Microwave Remote Sensing of the Atmosphere and Environment V 641014.

[69] Singh, K. K., Mishra, V. D., and Negi, H. S. 2007. "Evaluation of Snow Parameters Using Passive Microwave Remote Sensing.” Defence Science Journal 57 (2): 271-78.

[70] Singh, G., Venkataraman, G., Yamaguchi, Y., and Park, S. E. 2010. Temporal Snowpack Density Mapping Using $C$-Band Multi-Polarization ASAR Data. New York: IEEE.

[71] Macelloni, G., Paloscia, S., Pampaloni, P., Ruisi, R., Tedesco, M., Cagnati, A., and Valt, M. 2000. Microwave Emission of Snow in Alpine Regions and the Detection of Surface Hoar. New York: IEEE.

[72] Egli, L., Jonas, T., and Bettems, J. 2010. "A Virtual Network for Estimating Daily New Snow Water Equivalent and Snow Depth in the Swiss Alps”. Annals of Glaciology 51 (54): 32-8.

[73] Satterwhite, M., Mitchell, H., Hemmer, T., and Leckie, J. 2003. "Field Spectral Signatures of Snow, Ice, and Water”. Algorithms and Technologies for Multispectral, Hyperspectral and Ultraspectral Imagery 5093 (4): 528-37.

[74] Kapil, J., Joshi, S., and Rai, A. 2003. "In-situ Photoacoustic Investigations of Some Optically Transparent Samples like Ice and Snow”. Review of Scientific Instruments 74 (7): 3536-43.

[75] Satyawali, P. K., Schneebeli, M., Pielmeier, C., Stucki, T., and Singh, A. K. 2009. "Preliminary Characterization of Alpine Snow Using SnowMicroPen.” Cold Regions Science and Technology 55 (3): 311-20.

[76] Schreiber, H., Randeu, W., Schaffhauser, H., and Rammer, L. 2001. "Avalanche Dynamics Measurement by Pulsed Doppler Radar.” Annals of Glaciology 32: 275-80.

[77] Martinez-Vazquez, A., and Fortuny-Guasch, J. 2006. Feasibility of Snow Avalanche Volume Retrieval by GB-SAR Imagery. New York: IEEE.

[78] Martinez-Vazquez, A., and Fortuny-Guasch, J. 2007. Snow Avalanche Detection and Classification Algorithm for GB-SAR imagery. New York: IEEE.

[79] Martinez-Vazquez, A., and Fortuny-Guasch, J. 2008. "A GB-SAR Processor for Snow Avalanche Identification.” IEEE Transactions on Geoscience and Remote Sensing 46 (11): 3948-56.

[80] Mardirossian, G. 2007. "Application of Remote Sensing (Optical And Sar) to Monitoring Water Resources”.
Water Supply in Emergency Situations, Y. Sharan, A. Tal and H. Coccossis (Eds.), Springer, 115-23.

[81] Brennan, P. V., Ash, M., Isa, F. M., Keylock, C., and Mcelwaine, J. 2009. Advanced Adar Imaging of Geophysical Flows. Athens: World Scientific and Engineering Acad and Soc.

[82] Wang, L., and Brennan, P. 2009. "Avalanche Flow Imaging RADAR”. In Proceedings of 2009 IEEERadar Conference, Vols. 1 and 2, 779-82.

[83] Guan, Z. G., Lewander, M., Gronlund, R., Lundberg, H., and Svanberg, S. 2008. "Gas Analysis within Remote Porous Targets Using LIDAR Multi-Scatter Techniques”. Applied Physics B-Lasers and Optics 93(2-3): 657-63.

[84] Chrustek, P., and Wezyk, P. 2009. Using High Resolution Lidar Data to Estimate Potential Avalanche Release Areas on the Example of Polish Mountain Regions. Birmensdorf: Snow \& Landscape Res, Library Wsl.

[85] Pershin, S. M., Lyash, A. N., Makarov, V. S., Hamal, K., Prochazka, I., and Sopko, B. 2009. "Multilayers clouds monitoring by micro-joule lidar based on photon counting receiver and diode laser". Proc. SPIE 7355, Photon Counting Applications, Quantum Optics, and Quantum Information Transfer and Processing II, 73550S.

[86] Onacak, T., and Yurur, M. T. 2007. "A New High Precision Pluviometer System”. Instrumentation Science \& Technology 35 (5): 551-61.

[87] McCormack, E., and Stimberis, J. 2010. "Small Unmanned Aircraft Evaluated for Avalanche Control.” Transportation Research Record 2169: 168-73.

[88] Buchroithner, M., 1995. "Problems of Mountain Hazard Mapping Using Spaceborne Remote-Sensing Techniques”. Natural Hazards: Monitoring and Assessment using Remote Sensing Technique 15 (11): 57-66.

[89] Brandelik, A., Huebner, C., Bernier, M., and Schneebeli, M. 2002. "Vicarious Calibration for Remotely Sensed Hydro Power Water Resource”. Earth Observing Systems 4814 (7): 1-8.

[90] Naugolnykh, K., and Bedard, A. 2002. A Model of the Avalanche Infrasonic Radiation. New York: IEEE.

[91] Schmitt, U., Schardt, M., and Ninaus, J., 2002. Snow Avalanche Risk Assessment Supported by Remote Sensing. Leiden: AABalkema Publishers.

[92] Rao, Y. S., Venkataraman, G., and Singh, G. 2006. "ENVISAT-ASAR Data Analysis for Snow Cover Mapping Over Gangotri Region.” Proc. SPIE 6410, Microwave Remote Sensing of the Atmosphere and EnvironmentV, 641007.

[93] Schaffhauser, A., Adams, M., Fromm, R., Joerg, R., Luzi, G., Noferini, L., and Sailer, R. 2008. "Remote Sensing Based Retrieval of Snow Cover Properties”. Cold Regions Science and Technology54 (3): 164-75. 
[94] Schweizer, J., and Krusi, G. 2003. "Testing the Performance of Avalanche Transceivers.” Cold Regions Science and Technology 37 (3): 429-38.

[95] Salos, C. D., Lera, F. M., and Villarroel, J. L. 2007. Digital Signal Processing in Triple Antenna Arvas. New York: IEEE.

[96] Foster, J., Kelly, R., Rango, A., Armstrong, R., Erbe, E. F., Pooley, C., and Wergin, W. P. 2006. "Use of Low-Temperature Scanning Electron Microscopy to Compare and Characterize Three Classes of Snow Cover". Scanning 28 (4): 191-203.

[97] Surinach, E., Furdada, G., Sabot, F., Biescas, B., and Vilaplana, J. 2001. "On the Characterization of Seismic Signals Generated by Snow Avalanches for Monitoring Purposes.” Annals of Glaciology 32: 268-74.

[98] Hikida, M., Moriyama, M., and Nagai, Y. 2007. Warning System for Debris Flow Hazards at Sakurajima Volcano, Japan. Rotterdam: Millpress Science Publishers.

[99] Navarre, J., Bourova, E., Roulle, J., and Deliot, D. Y., 2009. The Seismic Detection of Avalanches: An Information Tool for the Avalanche Forecaster. Birmensdorf: Snow \& Landscape Res, Library Wsl.

[100] Valt, M., and Pesaresi, D. 2009. Detecting Snow Avalanches with Seismic Stations in North-East Italy: First Results of Dataset Analysis. Birmensdorf: Snow \& Landscape Res, Library Wsl.

[101] Van Herwijnen, A., and Schweizer, J. 2011. “Seismic Sensor Array for Monitoring an Avalanche Start Zone: Design, Deployment and Preliminary Results.” Journal of Glaciology 57 (202): 267-76.

[102] Shultz, E., and Albert, M., 1998. "An Automated Procedure for Plotting Snow Stratigraphy." In Proceedings of the Fifty-Fifth Annual Eastern Snow Conference, 147-51.

[103] Kronholm, K., and Birkeland, K. W., 2007. "Reliability of Sampling Designs for Spatial Snow Surveys". Computers \& Geosciences 33 (9): 1097-110.

[104] Prokop, A., Schirmer, M., Rub, M., Lehning, M., and
Stocker, M. 2008. “A Comparison of Measurement Methods: Terrestrial Laser Scanning, Tachymetry and Snow Probing for the Determination of the Spatial Snow-Depth Distribution on Slopes.” Annals of Glaciology 49: 210-16.

[105] Prokop, A., 2008. “Assessing the Applicability of Terrestrial Laser Scanning for Spatial Snow Depth Measurements.” Cold Regions Science and Technology 54 (3): 155-63.

[106] Prokop, A., 2009. Terrestrial Laser Scanning for Snow Depth Observations: An Update on Technical Developments and Applications. Birmensdorf: Snow \& Landscape Res, Library Wsl.

[107] Schirmer, M., Wirz, V., Clifton, A., and Lehning, M., 2011. "Persistence in Intra-Annual Snow Depth Distribution: 1. Measurements and Topographic Control,” Water Resources Research 47(W09516):1-16.

[108] Lundberg, A., 1997. "Laboratory Calibration of TDR-Probes for Snow Wetness Measurements.” Cold Regions Science and Technology 25 (3): 197-205.

[109] Stein, J., Laberge, G., and Levesque, D. 1997. "Monitoring the Dry Density and the Liquid Water Content of Snow Using TDR (Time Domain Reflectometry)." Cold Regions Science and Technology 25 (2): 123-36.

[110] Leprettre, B., and Martin, N., 2002. "Extraction of Pertinent Subsets from Time-Frequency Representations for Detection and Recognition Purposes.” Signal Processing 82 (2): 229-38.

[111] Denis, B., Keignart, J., Daniele, N. 2005. UWB Measurements and Propagation Models for Snowy Environments. New York: IEEE.

[112] Lipkova, J., and Cechak, J., 2005. Human Electromagnetic Emission in the ELF Band. Bratislava: Slovak Academy Sciences.

[113] Chamma, W. A., Mende, H., Barrie, G., and Robinson, R., 2007. Detection of Avalanche Victims Using Ultra-Wideband Short-Pulse Radar. New York: Springer. 